\title{
Vegetasi Tumbuhan pada Kawasan Tepi Hutan Taman Nasional Gunung Gede Pangrango yang Berbatasan dengan Kebun Raya Cibodas
}

\author{
MUSYAROFAH ZUHRI ${ }^{1}$, ZAENAL MUTAQIEN $^{1}$, DIAN R. NURDIANA $^{1}$, DESTRI $^{1}$, NUDIN $^{1}$, \\ DJUANDA $^{1}$
}

\author{
${ }^{1}$ Balai Konservasi Tumbuhan Kebun Raya Cibodas - LIPI \\ Jl. Kebun Raya Cibodas, Cipanas, Cianjur, Jawa Barat. 43253 \\ Email: ova_zuhri@yahoo.com
}

Received 2 June 2018; Received in revised form 27 June 2018;

Accepted 14 July 2018; Available online 26 November 2018

\begin{abstract}
Cibodas Botanic Garden area is adjacent with natural forest of Mt. Gede Pangrango National Park which consequences both vegetation in the border area are influence each other. The aims of this research were to study plant vegetation of forest area adjacent to Cibodas Botanical Garden and compare it with forest interior using transect method. The results showed that species richness in forest interior were higher than adjacent forest area. Furthermore, number of tree species, basal area and Shannon-Wienner diversity index in forest boundaries were higher rather than forest interior. Habitats along the forest edge were inhabited by trees with large dbh and low tree density. While trees inhibited forest interior areas with high density but small in size. The trees in forest interior were dominated by Schima wallichii, Lithocarpus pallidus and Turpinia sphaerocarpa. While trees in the forest boundary vegetation were dominated by Engelhardtia spicata, Litsea firma and Lithocarpus indutus. The tree age structure of forest interior and forest edge showed an inverted J-pattern and flat pattern respectively. Meanwhile, tree communities on edge forest vegetation showed similar age structure, especially in middle diameter class.
\end{abstract}

Keywords: Cibodas botanic garden, edge effect, forest border area, forest interior, Mt. Gede Pangrango national park

\section{INTISARI}

Kawasan Kebun Raya Cibodas yang berbatasan langsung dengan hutan alami Taman Nasional Gunung Gede Pangrango memiliki vegetasi yang saling terpengaruh satu sama lain. Tujuan dari penelitian ini adalah untuk mengetahui vegetasi tumbuhan pada kawasan hutan yang berbatasan langsung dengan Kebun Raya Cibodas dan membandingkannya dengan kawasan interior hutan yang belum terganggu dengan menggunakan metode transek. Hasil penelitian menunjukkan kekayaan tumbuhan pada interior hutan lebih tinggi dibandingkan batas hutan. Sementara itu jumlah jenis pohon, basal area, dan indeks keanekaragaman Shannon-Wienner untuk pohon pada batas hutan lebih tinggi dibandingkan interior hutan. Habitat sepanjang tepi hutan memiliki kepadatan yang lebih rendah dan dihuni oleh pohon dengan DBH besar. Sementara kawasan interior hutan memiliki kepadatan yang lebih tinggi namun dengan ukuran pohon yang lebih kecil. Dominasi tegakan pohon pada interior hutan adalah Schima wallichii, Lithocarpus pallidus dan Turpinia sphaerocarpa. Sedangkan pada vegetasi batas hutan didominasi oleh Engelhardtia spicata, Litsea firma dan Lithocarpus indutus. Struktur umur pohon pada interior hutan menunjukkan pola huruf $\mathrm{J}$ terbalik yang menunjukkan struktur umur yang tidak merata. Sementara itu komunitas pohon pada vegetasi tepi hutan menunjukkan struktur umur yang hampir sama terutama pada kelas diameter menengah.

Kata Kunci: efek tepi, hutan alami, interior hutan, Kebun Raya Cibodas, Taman Nasional Gunung Gede Pangrango

\section{PENDAHULUAN}

Keberadaan kebun raya di Indonesia tidak terlepas dari kepentingan di masa kolonial Belanda dengan tujuan awal dari pendirian kebun raya adalah sebagai tempat aklimatisasi tumbuhan bernilai ekonomi yang didatangkan dari berbagai negara (Surya dkk., 2003). Akan tetapi, pada saat ini tujuan utama dari kebun raya adalah sebagai tempat konservasi ex-situ tumbuhan asli Indonesia. Koleksi tumbuhan di kebun raya merupakan aset yang sangat berharga terutama bagi pengembangan ilmu di bidang pendidikan, kesehatan, taksonomi tumbuhan dan juga ekonomi (BGCI, 2012; Forbes, 2008).

Kebun Raya Cibodas sebagai salah satu kebun raya yang ada di Indonesia, secara geografis terletak di kaki Gunung Gede. Hal tersebut menyebabkan sebagian kawasan Kebun Raya Cibodas memiliki wilayah yang 
berbatasan langsung dengan hutan alami Taman Nasional Gunung Gede Pangrango (TNGGP). Kawasan Kebun Raya Cibodas yang berbatasan dengan hutan alami memiliki penggunaan lahan berupa hamparan kebun koleksi dan hutan sekunder yang terfragmen. Lebih lanjut, vegetasi Kebun Raya Cibodas memiliki peran sebagai border area atau daerah penyangga dan juga sebagai daerah transisi antara hutan dan habitat terbangun. Daerah peralihan antara dua vegetasi yang berbeda dapat memunculkan keragaman tumbuhan dan karakteristik unik yang disebabkan oleh perubahan faktor biotik dan abiotik diantara dua vegetasi yang berbeda atau disebut sebagai efek tepi (edge effect) (Kark et al., 2007; Kark and van Rensburg, 2006; Turner et al., 2003). Efek tepi dapat bersifat negatif terhadap kondisi fisik lingkungan (seperti radiasi, kelembaban, suhu udara, kecepatan angin dan hara tanah), keragaman dan komposisi tumbuhan, kompetisi dan predasi (Cochrane and Laurance, 2002; Molnár et al., 2001; Trombulak and Frissell, 2000).

Kawasan hutan Taman Nasional Gunung Gede Pangrango merupakan benteng pertahanan terakhir bagi konservasi tumbuhan khas pegunungan Jawa yang dilakukan secara in-situ. Tercatat 762 jenis tumbuhan yang terdiri dari pohon, perdu, semak, herba, epifit dan liana yang terdapat di kawasan Taman Nasional Gunung Gede Pangrango (Purnawan, 2006; Syahadat, 2006). Penelitian terhadap habitat tepi dari kawasan hutan alami TNGGP yang berbatasan langsung dengan Kebun Raya Cibodas belum pernah dilakukan sebelumnya sedangkan kawasan tersebut sendiri memiliki keunikan habitat yang belum pernah diteliti sebelumnya. Tujuan dari penelitian ini adalah untuk mengetahui vegetasi tumbuhan pada kawasan hutan yang berbatasan langsung dengan Kebun Raya Cibodas dan membandingkannya dengan vegetasi hutan alami (interior hutan) yang belum terganggu.

\section{METODE}

Penelitian dilakukan pada dua lokasi hutan yang berada di dalam TNGGP (Gambar 1) yaitu: (1) vegetasi tepi hutan yang merupakan kawasan TNGGP yang berbatasan langsung dengan areal kebun raya tepatnya dengan vak II.A; dan (2) vegetasi interior hutan yang berjarak 1,5 km dari batas hutan ke arah puncak gunung. Kawasan tersebut berada dalam zona pegunungan bawah (van Steenis, 2006) dengan ketinggian 1400-1600 mdpl, curah hujan rata-rata tahunan $2,950 \mathrm{~mm} / \mathrm{tahun}$, suhu udara rata-rata $20^{\circ} \mathrm{C}$, dan kelembaban rata-rata $80 \%$. Koordinat dan ketinggian untuk kedua lokasi tersaji dalam Tabel 1.

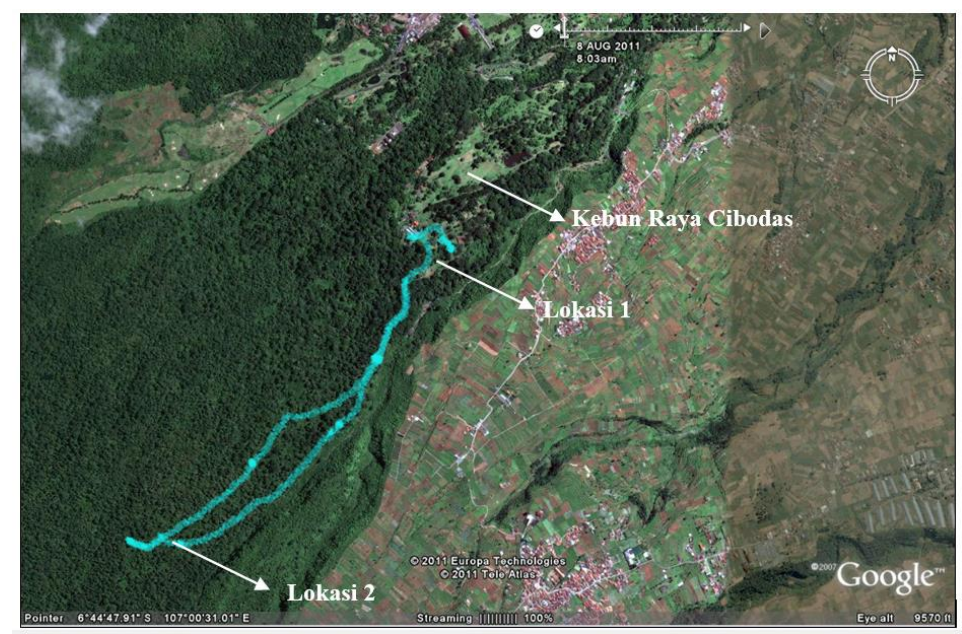

Gambar 1. Lokasi penelitian di kawasan TNGGP. Lokasi 1: vegetasi tepi hutan; Lokasi 2: vegetasi interior hutan

Tabel 1. Koordinat dan ketinggian lokasi penelitian

\begin{tabular}{ccc}
\hline Nama lokasi & Koordinat & Ketinggian (mdpl) \\
\hline \multirow{2}{*}{ Batas hutan } & S 644714 & 1450 \\
\hline
\end{tabular}




\begin{tabular}{ccc}
\hline Interior hutan & S 645229 & 1679 \\
\hline
\end{tabular}

Pengambilan Data. Pengambilan data vegetasi tumbuhan dilakukan dengan metode transek sepanjang $100 \mathrm{~m}$ dengan lebar $10 \mathrm{~m}$ mengikuti jalan setapak dari batas kebun raya ke dalam kawasan hutan. Parameter yang dicatat adalah nama jenis dan jumlah jenis untuk semua bentuk hidup (pohon, perdu dan herba). Pengukuran tinggi dan diameter setinggi dada (Diameter at Breast Height/DBH) dilakukan hanya untuk jenis pohon. Identifikasi dilakukan secara langsung di lapangan. Untuk jenis tumbuhan yang tidak dapat diidentifikasi maka dilakukan pengambilan voucher tumbuhan dan selanjutnya diidentifikasi dengan mencocokkan dengan herbarium yang ada di herbarium Cibodas. Bukaan tajuk diukur menggunakan kamera dan lensa fish eye yang diletakkan pada lantai hutan. Hasil foto kemudian dianalisis menggunakan perangkat lunak winscanopy untuk mengetahui persentase bukaan tajuk.

Analisis Data. Parameter vegetasi yang diamati meliputi kerapatan, frekuensi, dan kerimbunan yang dinyatakan dalam luas basal area diestimasi dari hasil pengukuran $\mathrm{DBH}$ untuk jenis pohon. Sementara itu data yang dianalisis meliputi indeks nilai penting (INP), indeks keanekaragaman Shannon-Wienner (Odum, 1971), indeks kesamaan yang merupakan komplemen dari indeks ketidaksamaan Bray-Curtis (Krebs, 1999) dengan menggunakan rumus di bawah ini. Stratifikasi pohon dilakukan berdasarkan kelas diameter dan tinggi pohon.

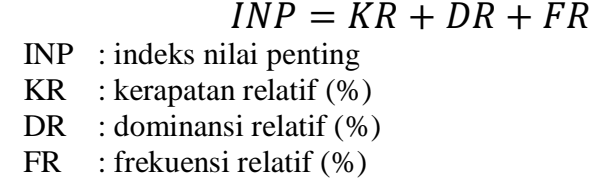

$$
H^{\prime}=-\sum_{i=1}^{n}\left[\frac{n_{i}}{N} \ln \frac{n_{i}}{N}\right]
$$

$\mathrm{H}^{\prime} \quad$ : indeks keanekaragaman jenis

$n_{i} \quad$ :jumlah individu jenis ke-n

$\mathrm{N}$ : total jumlah individu

$$
B=\frac{\sum\left|X_{i j}-X_{i k}\right|}{\sum\left|X_{i j}+X_{i k}\right|}
$$

Indeks kesamaan $=1,0-B$

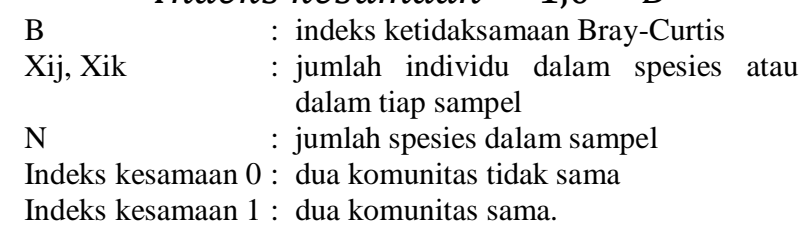

\section{HASIL}

Kekayaan Tumbuhan. Kekayaan tumbuhan di kedua lokasi penelitian menunjukkan hasil yang berbeda. Secara umum kekayaan jenis pada interior hutan lebih tinggi dibandingkan batas hutan. Pada interior hutan total terdapat 69 jenis tumbuhan yang terdiri dari pohon, perdu, herba, paku-pakuan, dan pemanjat berkayu. Bentuk hidup epifit dan palem tidak hadir di vegetasi interior hutan. Sementara itu pada batas hutan terdapat 60 jenis tumbuhan dengan semua bentuk hidup hadir di vegetasi batas hutan (Tabel 2). Daftar jenis tumbuhan secara lengkap dapat dilihat pada Tabel 3.

\begin{tabular}{|c|c|c|}
\hline \multirow{2}{*}{ Bentuk hidup } & \multicolumn{2}{|c|}{ Jumlah Jenis } \\
\hline & Interior Hutan & Batas Hutan \\
\hline Pohon & 15 & 21 \\
\hline Perdu & 23 & 17 \\
\hline Herba & 21 & 14 \\
\hline Epifit & - & 2 \\
\hline Paku-pakuan & 6 & 3 \\
\hline Pemanjat berkayu & 4 & 1 \\
\hline Palem & - & 2 \\
\hline & 69 & 60 \\
\hline
\end{tabular}

Tabel 2. Jumlah jenis pada berbagai bentuk hidup 
Tabel 3. Komposisi vegetasi untuk bentuk hidup pohon kecil, perdu, palem dan herba

\begin{tabular}{|c|c|c|c|}
\hline \multirow{2}{*}{\multicolumn{2}{|c|}{ Interior Hutan }} & \multicolumn{2}{|c|}{ Area Batas Hutan } \\
\hline & & \multicolumn{2}{|l|}{ Pohon } \\
\hline Acronychia sp. & & Castanopsis argentea & Magnolia montana \\
\hline Castanopsis argentea & & Cestrum aurantiacum* & Ostodes paniculata \\
\hline Castanopsis javanica & & Cinchona pubescens* & Persea rimosa \\
\hline Cinnamomum sintok & & Cryptocarya ferrea & Polyalthia subcordata \\
\hline Ficus alba & & Dysoxylum nutans & Pyrenaria serrata \\
\hline Ficus ribes & & Ehretia javanica & Rauvolfia javanica \\
\hline Glochidion cyrtostylum & & Elaeocarpus sphaericus & Saurauia cauliflora \\
\hline Saurauia pendula & & Elaeocarpus submonoceras & Saurauia pendula \\
\hline Turpinia sphaerocarpa & & Euonymus javanicus & Saurauia reinwardtiana \\
\hline Vernonia arborea & & Eurya chinensis & Sloanea sigun \\
\hline Viburnum lutescens & & Ficus ribes & Symplocos costata \\
\hline Viburnum sambucinum & & Flacourtia rukam & Syzygium pycnanthum \\
\hline \multirow[t]{5}{*}{ Villebrunea rubescens } & & Glochidion cyrtostylum & Syzygium racemosum \\
\hline & & Helicia serrata & Turpinia sphaerocarpa \\
\hline & & Lithocarpus indutus & Vernonia arborea \\
\hline & & Litsea firma & Viburnum lutescens \\
\hline & & $\begin{array}{l}\text { Macropanax dispermus } \\
\text { Magnolia liliifera }\end{array}$ & Villebrunea rubescens \\
\hline \multicolumn{4}{|c|}{ Perdu } \\
\hline \multirow[t]{4}{*}{ Trevesia sundaica } & & Ardisia fuliginosa & Lasianthus purpureus \\
\hline & & Clerodendrum eriosiphon & Lasianthus rigidus \\
\hline & & Dendrocnide stimulans & Lasianthus stercorarius \\
\hline & & Lasianthus laevigatus & Trevesia sundaica \\
\hline \multicolumn{4}{|c|}{ Herba } \\
\hline Acronychia sp. & Glochidion sp. & Amomum sp. & Peristrophe sp. \\
\hline Amomum coccineum & Homalanthus sp. & Arisaema filiforme & Pilea melastomoides \\
\hline Arisaema filiforme & Lasianthus laevigatus & Breynia sp. & Polyalthia subcordata \\
\hline Begonia robusta & Lasianthus sp. & Clerodendrum sp. & Polyosma sp. \\
\hline Blumea balsamifera & Lasianthus stercorarius & Commelina sp. & Ranunculus javanicus \\
\hline Breynia sp. & Musa sp. & Dendrocnide stimulans & Rubus moluccanus \\
\hline Claoxylon longifolium & Mussaenda frondosa & Etlingera sp. & Strobilanthes laevigata \\
\hline Cyperus sp. & Mycetia $\mathrm{sp}$. & Itea macrophylla & Tropidia sp. \\
\hline Didymocarpus sp. & Pilea melastomoides & Medinilla speciosa & Zingiber sp. \\
\hline Elatostema nigrescens & Polygala venenosa & Mussaenda frondosa & \\
\hline Elatostema sp. & Psychotria sp. & Pandanus furcatus & \\
\hline Etlingera sp. & Rubus moluccanus & & \\
\hline Eupatorium pallescens & Schefflera scandens & & \\
\hline \multirow{2}{*}{\multicolumn{2}{|c|}{$\begin{array}{l}\text { Eupatorium riparium } \\
\text { Fagraea scandens }\end{array}$}} & & \\
\hline & & & \\
\hline
\end{tabular}

Fagraea scandens

\begin{tabular}{lc}
\hline Pinanga coronata & Palem \\
& Pinanga coronata \\
Pinanga javana
\end{tabular}

Ket: * Tumbuhan jenis asing

Jumlah jenis pohon, epifit dan palem pada vegetasi batas hutan lebih tinggi dibandingkan vegetasi interior hutan. Sementara itu jumlah jenis untuk perdu, herba, paku-pakuan, dan pemanjat berkayu lebih tinggi pada interior hutan dibandingkan batas hutan. Sebanyak 21 jenis pohon terdapat di kawasan batas hutan yang didominasi oleh Engelhardtia spicata, Litsea firma dan Lithocarpus indutus. Jumlah tersebut lebih tinggi dibandingkan jumlah jenis pohon di areal interior hutan. Sementara itu anakan pohon menunjukkan hal yang sebaliknya, jumlah jenis anakan pohon lebih banyak di interior hutan dibandingkan di batas hutan yaitu sebanyak 23 jenis.

Jumlah jenis perdu pada vegetasi batas hutan lebih tinggi dibandingkan di interior hutan alami (Tabel 2). Trevesia sundaica yang merupakan perdu dari suku Araliaceae ditemui di vegetasi hutan alami dan juga pada batas hutan (Tabel 3). Jenis tersebut merupakan tumbuhan pioneer yang banyak ditemui di 
kawasan hutan yang terbuka. Terdapat 8 jenis perdu pada vegetasi batas hutan, yaitu Ardisia fuliginosa, Clerodendrum eriosiphon, Dendrochnide stimulans, Lasianthus laevigatus, L. purpureus, L. rigidus, $L$. stercorarius dan Trevesia sundaica. Gambar beberapa jenis tumbuhan yang dominan dan menarik di lokasi penelitian ditampilkan pada Gambar 2.

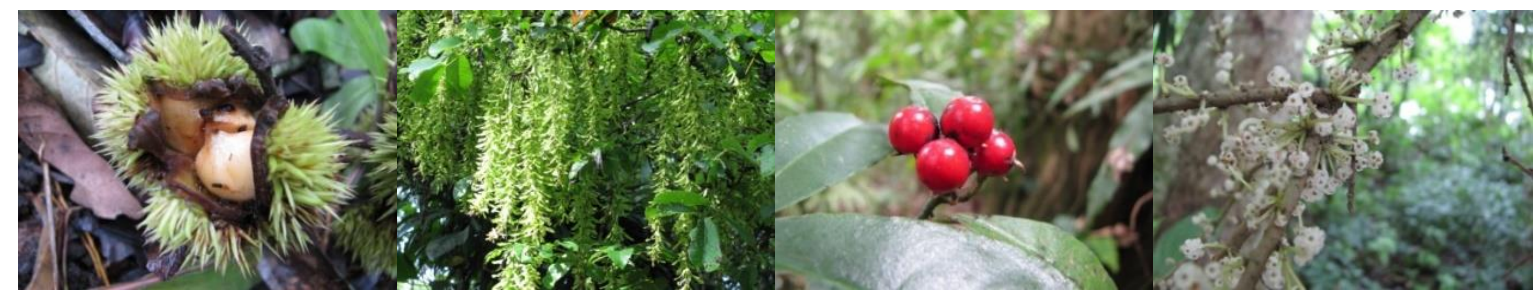

A

B

C

D

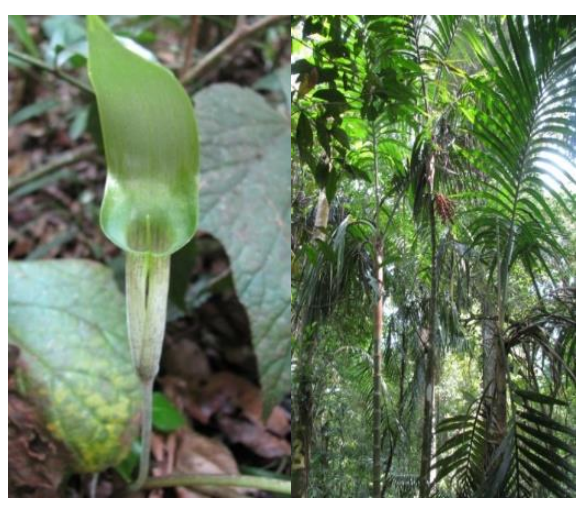

E

$\mathrm{F}$

Gambar 2. Beberapa jenis tumbuhan dominan dan menarik di lokasi penelitian: (a) Castanopsis argentea; (b) Engelhardtia spicata; (c) Ardisia villosa; (d) Villebrunea rubescens; (e) Arisaema filiforme; (f) Pinanga coronata.

Jumlah jenis herba di interior hutan lebih tinggi dibandingkan di batas hutan, yaitu sebesar 21 jenis. Lebih lanjut, bukaan tajuk pada batas hutan menunjukkan angka yang lebih tinggi dibandingkan di areal interior hutan (Tabel 4; Gambar 3).

Tabel 4. Persentase bukaan tajuk di kawasan penelitian

\begin{tabular}{cc}
\hline Lokasi & Bukaan Tajuk (\%) \\
\hline Interior hutan & 19,69 \\
Batas hutan & 36,37 \\
\hline
\end{tabular}

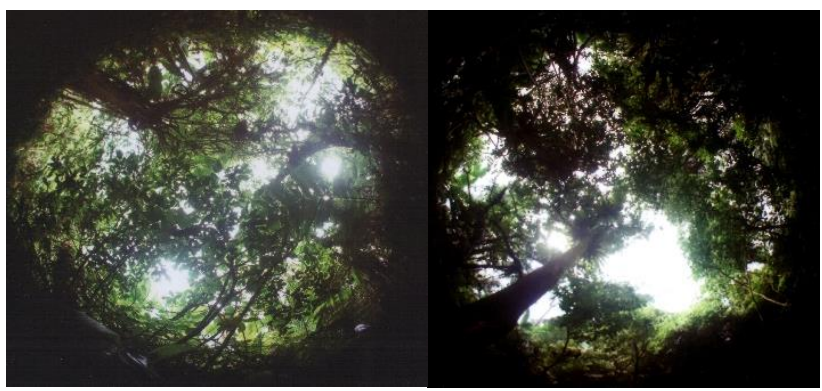

A

B

Gambar 3. Bukan tajuk pada (a) batas hutan; dan (b) interior hutan 

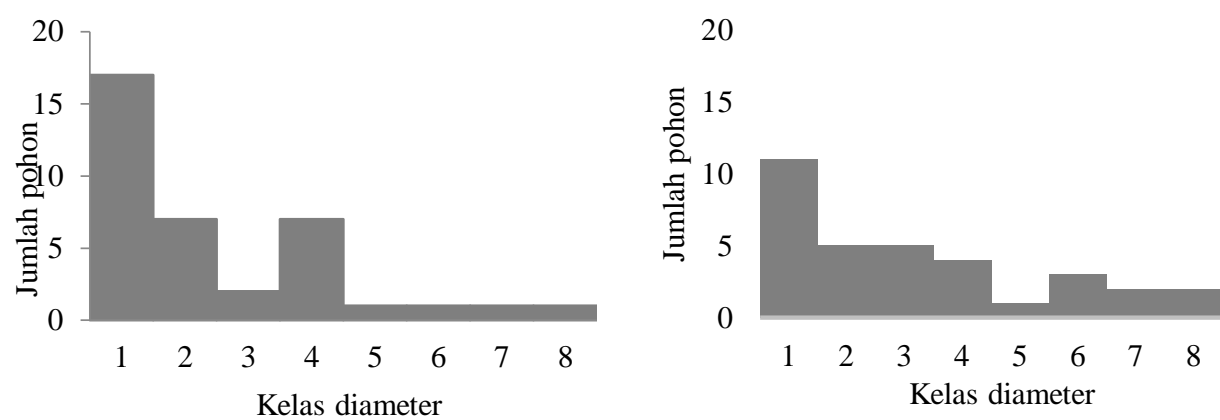

Gambar 4. Distribusi kelas diameter pohon pada (a) interior hutan dan (b) batas hutan. Keterangan: Kelas diameter 1=0$10 \mathrm{~cm} ; 2=10-20 \mathrm{~cm} ; 3=20-30 \mathrm{~cm} ; 4=30-40 \mathrm{~cm} ; 5=40-50 \mathrm{~cm} ; 6=50-60 \mathrm{~cm} ; 7=60-70 \mathrm{~cm} ; 8=70-80 \mathrm{~cm} ; 9=80-90 \mathrm{~cm}$.

Kekayaan Jenis Pohon. Kepadatan pohon di interior hutan menunjukkan jumlah yang lebih tinggi dibandingkan batas hutan, namun jumlah jenis pohon menunjukkan hal yang sebaliknya. Di kawasan interior hutan, kepadatan pohon mencapai 38 pohon/0,1 ha dengan jumlah 15 jenis pohon. Sementara itu di kawasan batas hutan kepadatan pohon sebesar 32 pohon/0,1 ha dengan jumlah 21 jenis pohon (Tabel 5). Basal area dan indeks keanekaragaman Shannon-Wienner pada batas hutan menunjukkan angka yang lebih tinggi dibandingkan interior hutan. Untuk kawasan batas hutan, basal area sebesar 4,98 $\mathrm{m}^{2}$ dengan H' 3,7.

Tabel 5. Kekayaan jenis untuk tegakan pohon $\mathrm{dbh}>10 \mathrm{~cm}$

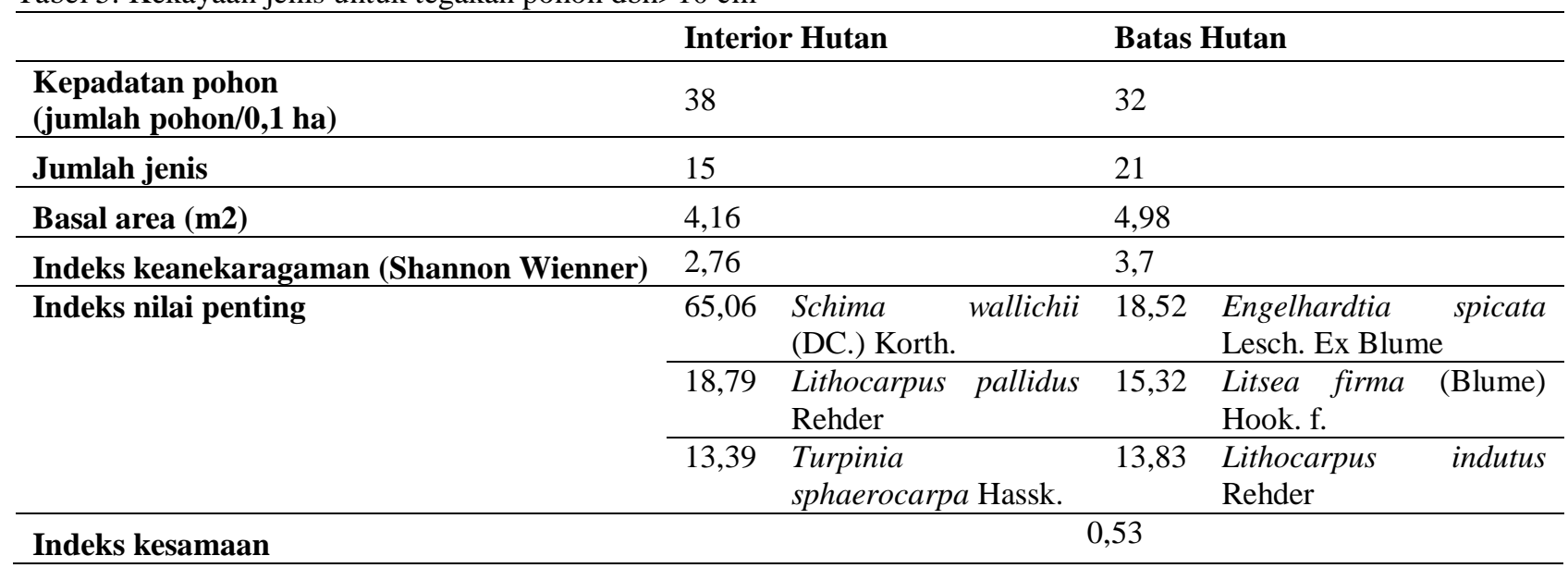

\section{Stratifikasi Pohon Berdasarkan Kelas}

Diameter. Pada interior hutan, tegakan pohon didominasi oleh Schima wallichii, Lithocarpus pallidus dan Turpinia sphaerocarpa yang kesemuanya merupakan jenis tumbuhan asli penyusun hutan pegunungan atas. Sementara itu tegakan pohon pada vegetasi batas hutan didominasi oleh Engelhardtia spicata, Litsea firma dan Lithocarpus indutus. Selain itu juga ditemukan jenis tumbuhan asing yaitu Cestrum aurantiacum dan Calliandra calothyrsus (Tabel 3). Gambar 4 menunjukkan distribusi diameter pohon di kedua jenis vegetasi. Struktur umur pohon pada komunitas pohon di interior hutan menunjukkan pola huruf $\mathbf{J}$ terbalik sebagai struktur umur yang tidak merata. Sementara itu komunitas pohon pada vegetasi hutan tepi menunjukkan pola yang hampir rata terutama pada kelas diameter menengah $(10-20 \mathrm{~cm}, 20-30 \mathrm{~cm}$ dan $30-40$ $\mathrm{cm})$.

Stratifikasi Pohon Berdasarkan Tinggi. Pada penelitian ini stratifikasi berdasarkan kelas tinggi dibagi menjadi 4 kelas atau strata, yaitu strata 1 untuk pohon dengan tinggi $>26$ $\mathrm{m}$, strata 2 untuk pohon dengan tinggi 25-26 $\mathrm{m}$, strata 3 pohon dengan tinggi $6-25 \mathrm{~m}$, dan strata 4 untuk pohon dengan tinggi $<6 \mathrm{~m}$ (Tabel 6 dan 7). Pada vegetasi interior hutan terdapat Schima wallichii yang merupakan pohon emergen dengan ketinggian maksimal mencapai $35 \mathrm{~m}$. Selain itu pada strata atas 
(tinggi pohon $>26 \mathrm{~m}$ ) juga diduduki oleh Ficus involucrata, Lithocarpus pallidus, Castanopsis javanica dan Manglietia glauca dengan basal area mencapai $1,63 \mathrm{~m}^{2}$. Indeks keanekaragaman $\left(\mathrm{H}^{\prime}\right)$ tertinggi terdapat pada strata 3 (pohon dengan tinggi 25-6 m) yang mencapai 2,48 yang terdiri dari 20 pohon. Pada strata yang lebih rendah (strata 4 tinggi pohon $<6 \mathrm{~m}$ ) terdapat 26 pohon dan 4 buah palem dengan $\mathrm{dbh}<10 \mathrm{~cm}$ dan tinggi $>1,3 \mathrm{~m}$.

Tabel 6. Data pohon di tiap strata pada vegetasi interor hutan

\begin{tabular}{|c|c|c|c|c|c|c|}
\hline & & Strata 1 & Strata 2 & Strata 3 & Strata 4 & Total \\
\hline \multirow[t]{4}{*}{$\mathrm{dbh}>10 \mathrm{~cm}$} & Jumlah pohon & 4 & 10 & 20 & 4 & 38 \\
\hline & Basal area $\mathrm{m} 2$ & 1,63 & 1,19 & 1,23 & 0,07 & 4,12 \\
\hline & $\begin{array}{l}\text { Jumlah jenis yang ditambahkan ke } \\
\text { layer selanjutnya }\end{array}$ & 2 & 4 & 9 & 0 & 15 \\
\hline & $\begin{array}{l}\text { Indeks keanekaragaman Shannon- } \\
\text { Wiener }\end{array}$ & 0,56 & 1,05 & 2,48 & 0,69 & 4,78 \\
\hline \multirow{2}{*}{$\begin{array}{l}\text { dbh }<10 \mathrm{~cm} \mathrm{\&} \\
\text { tinggi }>1,3 \mathrm{~m}\end{array}$} & Jumlah pohon & & & 4 & 26 & 30 \\
\hline & Basal area $\mathrm{m} 2$ & & & 0,018 & 0,034 & 0,052 \\
\hline \multirow[t]{2}{*}{ Palem } & Jumlah palem & & & & 4 & 4 \\
\hline & Basal area $\mathrm{m} 2$ & & & & 0,004 & 0,004 \\
\hline
\end{tabular}

Ket: Strata $1>26$ m; strata 2: 26-25m; strata 3: 25-6m; strata $4<6$ m

Tabel 7. Data pohon pada tiap strata di vegetasi batas hutan

\begin{tabular}{|c|c|c|c|c|c|c|}
\hline & & Strata 1 & Strata 2 & Strata 3 & Strata 4 & Total \\
\hline \multirow[t]{4}{*}{$\mathrm{dbh}>10 \mathrm{~cm}$} & Jumlah pohon & 5 & 12 & 12 & 3 & 32 \\
\hline & Basal area $\mathrm{m} 2$ & 2,23 & 2,13 & 0,41 & 0,04 & 4,81 \\
\hline & $\begin{array}{l}\text { Jumlah jenis yang ditambahkan ke } \\
\text { layer selanjutnya }\end{array}$ & 5 & 8 & 5 & 3 & 21 \\
\hline & $\begin{array}{l}\text { Indeks keanekaragaman Shannon- } \\
\text { Wiener }\end{array}$ & 1,59 & 2,09 & 1,8 & 1,08 & 6,56 \\
\hline \multirow{2}{*}{$\begin{array}{l}\text { dbh }<10 \mathrm{~cm} \& \\
\text { tinggi }>1,3 \mathrm{~m}\end{array}$} & Jumlah pohon & & & 10 & 99 & 109 \\
\hline & Basal area $\mathrm{m} 2$ & & & 0,04 & 0,13 & 0,17 \\
\hline \multirow[t]{2}{*}{ Palem } & Jumlah palem & & & 2 & 28 & 30 \\
\hline & Basal area $\mathrm{m} 2$ & & & 0,003 & 0,031 & 0,034 \\
\hline
\end{tabular}

Ket: Strata 1>26 m; strata 2: 26-25m; strata 3: 25-6m; strata 4<6 m

\section{PEMBAHASAN}

Area batas hutan memiliki keanekaragaman yang lebih tinggi sebab area tersebut merupakan zona peralihan dari vegetasi kebun raya ke vegetasi hutan alami sehingga vegetasi yang berada di area tersebut memiliki komposisi unik yang merupakan perpaduan antara dua vegetasi yang bersebelahan. Sementara itu, habitat sepanjang tepi hutan memiliki kepadatan yang lebih rendah dan dihuni oleh pohon dengan dbh besar. Kawasan interior hutan memiliki kepadatan yang lebih tinggi namun dengan ukuran pohon yang lebih kecil.

Kawasan Kebun Raya Cibodas bersinggungan secara langsung dengan kawasan TNGGP dalam bentuk kebun koleksi dan hutan sisa (remnant forest). Pemecaran tumbuhan di kedua kawasan tersebut tidak dapat dibatasi oleh wilayah pengelolaan ataupun pagar yang membentang. Oleh karena itu, area batas hutan merupakan habitat transisi yang dipengaruhi oleh dua vegetasi yang berbatasan. Perbedaan komposisi dan struktur vegetasi dapat dilihat dari jumlah jenis, kekayaan jenis pohon, stratifikasi pohon berdasarkan kelas diameter dan tinggi.

Daerah tepi memiliki kepadatan pohon yang lebih tinggi dibandingkan dengan daerah interior (Harper et al., 2005; Hill and Curran, 2003; Kacholi, 2014). Hasil penelitian kali ini kurang sejalan dengan hal tersebut, namun ini menunjukkan tingginya variasi yang terjadi pada hutan tropis dataran tinggi dengan kondisi dari tiap kawasan mungkin akan berbeda dari satu tempat ke tempat lain. Lebih tingginya jumlah jenis perdu, herba dan anakan pohon di vegetasi batas hutan dapat disebabkan oleh persentase bukaan tajuk pada batas hutan yang mencapai $36,37 \%$ jauh lebih 
tinggi daripada bukaan tajuk pada interior hutan yang hanya sebesar $19,69 \%$. Bukaan tajuk berperan dalam memberikan cahaya bagi tumbuhan bawah (Beckage et al., 2000; Montti et al., 2011).

Menurut Coomes and Allen (2007) pada hutan pegunungan, semakin tinggi elevasi maka ukuran pohon akan semakin kecil dengan kepadatan yang lebih tinggi. Pengaruh elevasi sedikit banyak juga ikut berperan dalam penurunan kekayaan jenis pada kawasan interior hutan alami. Pada penelitian ini vegetasi batas hutan berada pada ketinggian 1,450 mdpl sementara hutan interior berada pada ketinggian 1,679 mdpl. Indeks kesamaan yang merupakan komplemen dari indeks ketidaksamaan Bray-Curtis menunjukkan komunitas pohon pada vegetasi interior hutan dan batas hutan relatif tidak sama yaitu sebesar 0,53 . Indeks kesamaan yang mendekati 1 menunjukkan dua komunitas sama. Penelitian yang dilakukan di kawasan hutan Tanzania menunjukkan indeks kesamaan antara habitat tepi dengan kawasan intermediate sebesar 0,681 (Kacholi, 2014). Hal tersebut menunjukkan habitat tepi memiliki vegetasi yang relatif berbeda dengan kawasan interior.

Struktur umur pohon pada komunitas pohon di interior hutan yang menunjukkan pola huruf $\mathrm{J}$ terbalik menunjukkan struktur umurnya tidak merata. Pola tersebut lazim ditemukan pada hutan yang mencapai tahapan klimaks. Pada kelas diameter kecil di vegetasi batas hutan, kerapatan pohon sangat tinggi. Hal tersebut dapat disebabkan oleh laju kolonisasi dan pergantian (turnover) yang cepat. (Meinzer, 2003; Montgomery and Chazdon, 2001). Sementara itu komunitas pohon pada vegetasi hutan tepi menunjukkan pola yang hampir rata terutama pada kelas diameter menengah. Pola ini banyak ditemukan pada hutan sekunder yang terganggu.

Stratifikasi hutan berdasarkan tinggi pada vegetasi batas hutan menunjukkan pola yang relatif seragam. Lebih banyak pohon besar emergen yang ditemukan, antara lain Ehretia javanica (ketinggian maksimal $35 \mathrm{~m}$ ), Litsea firma, Castanopsis javanica, Castanopsis argentea, dan Engelhardtia spicata. Meskipun berada di areal batas hutan namun beberapa jenis emergen tersebut dahulu merupakan pohon koleksi Kebun Raya Cibodas. Hal tersebut dibuktikan dari adanya papan nama pohon khas Kebun Raya Cibodas yang masih terpasang.

Terdapat 3 tumbuhan jenis asing yang ditemui hanya di kawasan batas hutan, yaitu Cestrum aurantiacum, Cinchona pubescens dan Chimonobambusa quadrangularis. Jenis tumbuhan asing tersebut merupakan pengaruh dari vegetasi kebun raya yang berbatasan dengan hutan. Hal tersebut sejalan dengan teori efek tepi yang memperkirakan bahwa jenis pendatang akan lebih banyak ditemukan pada habitat tepi (Cadenasso and Pickett, 2001; Holway, 2005).

C. aurantiacum merupakan jenis perdu atau pohon kecil berbentuk terompet kecil dan bunga jingga yang sangat mencolok sehingga mengundang burung untuk menyerbukinya. Sebagai pendatang dari Amerika Selatan, keberadaan $C$. aurantiacum telah liar secara lokal di bagian tepi hutan Jawa pada ketinggian lebih dari $1.000 \mathrm{~m}$ dpl (Rambuda and Johnson, 2004; Sivaraj et al., 2015; van Steenis, 2006).

C. pubescens merupakan jenis tumbuhan awal yang diintroduksi ke Kebun Raya Cibodas sebagai tumbuhan obat untuk penyakit malaria. Lokasi ditemukannya $C$. pubescens di tepi hutan tidak jauh dari tempat C. pubescens ditanam yaitu di vak II.A. Merupakan pohon anggota Rubiaceae dengan tinggi dapat mencapai $20 \mathrm{~m}$ dan sistem perbungaan berbentuk paniculata. $C$. pubescens termasuk jenis tumbuhan asing invasif yang dapat hidup pada kisaran ketinggian 300-3900 m. Di Indonesia, $C$. pubescens mulai diperkenalkan pada zaman penjajahan Belanda dan sengaja dibudidayakan di berbagai perkebunan teh sebagai tanaman keras. Namun pada saat ini keberadaannya telah banyak menyebar di hutan alam yang berada di sekitar perkebunan.

C. quadrangularis merupakan jenis tumbuhan bambu dengan batang kecil dan tinggi mencapai $3 \mathrm{~m}$. Penyebaran $C$. quadrangularis telah jauh masuk ke dalam kawasan hutan TNGGP sampai dengan jarak 
$50 \mathrm{~m}$ dari batas hutan. C. quadrangularis menginvasi dengan cara perbanyakan individu melalui stolon yang dapat mencapai kedalaman setengah meter ke dalam tanah dan dengan jarak yang sangat jauh. Banyaknya anakan yang dihasilkannya menciptakan kondisi lingkungan dengan intensitas cahaya yang rendah. Hal tersebut menyebabkan jenis tumbuhan bawah yang membutuhkan cahaya matahari untuk pertumbuhannya tidak dapat bertahan hidup. Selain itu serasah daun yang dihasilkan oleh $C$. quadrangularis sangat banyak dan telah lama terdegradasi sehingga menghasilkan lapisan yang cukup tebal.

\section{KESIMPULAN}

Hutan di daerah tepi memiliki jumlah jenis pohon, basal area dan indeks keanekaragaman Shannon-Wiener yang lebih tinggi dibandingkan bagian hutan interior. Hal tersebut dimungkinkan oleh pengaruh dari efek tepi dengan area batas hutan merupakan daerah persinggungan antara habitat Kebun Raya Cibodas dan habitat interior hutan alami. Dominasi tegakan pohon pada hutan interior adalah Schima wallichii, Lithocarpus pallidus dan Turpinia sphaerocarpa. Sementara itu tegakan pohon pada vegetasi batas hutan didominasi oleh Engelhardtia spicata, Litsea firma dan Lithocarpus indutus.

\section{UCAPAN TERIMA KASIH}

Terima kasih kepada Balai Besar Taman Nasional Gunung Gede Pangrango dan Balai Konservasi Tumbuhan Kebun Raya Cibodas yang telah memfasilitasi tempat penelitian. Serta terima kasih kepada Bapak Emus dan semua pihak yang telah membantu pelaksanaan kegiatan penelitian ini.

\section{DAFTAR PUSTAKA}

Beckage B, Clark JS, Clinton BD, Haines B. L. 2000. A long-term study of tree seedling recruitment in southern Appalachian forests: the effects of canopy gaps and shrub understories. Can. J. For. Res. vol 30(10): 1617-1631. https://doi.org/10.1139/x00-075.

BGCI. 2012. International agenda for Botanic gardens in Conservation. 2nd edition.
Richmond UK: Botanic Gardens Conservation International. https://doi.org/10.1016/S00256196(11)60604-6.

Cadenasso ML, and Pickett STA. 2001. Effect of edge structure on the flux of species into forest interiors. Conservation Biology. vol 15(1): 91-97. https://doi.org/10.1046/j.15231739.2001.99309.x.

Cochrane MA, and Laurance WF. 2002. Fire as a large-scale edge effect in Amazonian forests. Journal of Tropical Ecology. vol 18(3):

311-325. https://doi.org/https://doi.org/10.1017/S0 266467402002237

Coomes DA, and Allen RB. 2007. Effects of size, competition and altitude on tree growth. Journal of Ecology. vol 95(5): 1084-1097. https://doi.org/10.1111/j.13652745.2007.01280.x

Forbes S. 2008. How Botanic Gardens Changed the World. The History and Future of Social Innovation Cenference. Adelaide: University of South Australia. pp. 1-4.

Harper KA, Macdonald SE, Burton PJ, Chen J, Brosofske KD, Saunders SC, Euskircehn ES. 2005. Edge influence on forest structure and composition in fragmented landscapes. Conservation Biology. vol 19(3): 768-782. https://doi.org/10.1111/j.15231739.2005.00045.x.

Hill JL, and Curran PJ. 2003. Area, shape and isolation of tropical forest fragments: Effects on tree species diversity and implications for conservation. Journal of Biogeography. vol 30(9): 1391-1403. https://doi.org/10.1046/j.1365-

2699.2003.00930.x.

Holway DA. 2005. Edge effects of an invasive species across a natural ecological boundary. Biological Conservation. vol 121(4): 561-567. https://doi.org/10.1016/j.biocon.2004.06. 005.

Kacholi DS. 2014. Edge-Interior Disparities in Tree Species and Structural Composition 
of the Kilengwe Forest in Morogoro Region, Tanzania. ISRN Biodiversity. vol 2014: $1-8$. https://doi.org/10.1155/2014/873174.

Kark S, Allnutt TF, Levin N, Manne LL, Williams PH. 2007. The role of transitional areas as avian biodiversity centres. Global Ecology and Biogeography. vol 16(2): 187-196. https://doi.org/10.1111/j.14668238.2006.00274.x.

Kark S, and van Rensburg BJ. 2006. Ecotones: Marginal or Central Areas of Transition? Israel Journal of Ecology \& Evolution. vol 52(1): 29-53. https://doi.org/10.1560/IJEE.52.1.29.

Krebs JC. 1999. Ecological Methology. 2nd Edition. Menlo Park: Benjamin Cummings.

Meinzer FC. 2003. Functional convergence in plant responses to the environment. Oecologia. vol 134(1): 1-11. https://doi.org/10.1007/s00442-0021088-0.

Molnár T, Magura T, Tóthmérész B, Elek Z. 2001. Ground beetles (Carabidae) and edge effect in oak-hornbeam forest and grassland transects. European Journal of Soil Biology. vol 37(4): 297-300. https://doi.org/10.1016/S11645563(01)01103-7.

Montgomery RA, and Chazdon RL. 2001. Forest structure, canopy architecture, and light transmittance in tropical wet forests. Ecology. vol 82(10): 2707-2718. https://doi.org/10.1890/0012-

9658(2001)082[2707:FSCAAL]2.0.CO;2

Montti L, Campanello PI, Gatti MG, Blundo C, Austin AT, Sala OE, Goldstein G. 2011. Understory bamboo flowering provides a very narrow light window of opportunity for canopy-tree recruitment in a neotropical forest of Misiones, Argentina. Forest Ecology and Management. vol 262(8): 1360-1369. https://doi.org/10.1016/j.foreco.2011.06.0 29.

Odum E. 1971. Fundamentals of Ecology. Philadelphia: W.B. Sounders Company Ltd.
Purnawan BI. 2006. Inventarisasi keanekaragaman jenis tumbuhan di taman nasional Gunung Gede Pangrango [Skripsi]. Bogor: Institut Pertanian Bogor.

Rambuda TD, and Johnson SD. 2004. Breeding systems of invasive alien plants in South Africa: Does Baker's rule apply? Diversity and Distributions. vol 10(5-6): 409-416. https://doi.org/10.1111/j.13669516.2004.00100.x.

Sivaraj B, Vidya C, Nandini S, Sanil R. 2015. Antimicrobial Activity of Cestrum aurantiacum L. International Journal of Current Microbiology and Applied Sciences. vol 4(3): 830-834.

Surya MI, Lailati M, Ekasari I, Nurlaeni Y, Astutik S, Normasiwi S, Gumilang AR, Junaedi DI, Mutaqien Z, Nurdiana DR, Rahman W, Destri, Rozak AH. 2003. Konservasi Tumbuhan di Kebun Raya Cibodas Sebagai Penyelamat Keanekaragaman Hayati Pegunungan di Indonesia. Lokakarya Nasional Kenaekaragaman Hayati Sebagai Modal Dasar Pembanguna. Bogor: Kementerian Lingkungan Hidup dan Kehutanan. hal 114.

Syahadat E. 2006. Faktor-Faktor yang Mempengaruhi Kunjungan wisatawan di Taman Nasional Gede Pangrango (TNGP). Jurnal Penelitian Sosial Dan Ekonomi Kehutanan. vol 3(1): 1-14.

Trombulak SC, and Frissell CA. 2000. Review of ecological effects of roads on terrestrial and aquatic communities. Conservation Biology. vol 14(1): 18-30. https://doi.org/10.1046/j.15231739.2000.99084.x.

Turner NJ, Davidson-Hunt IJ, O'Flaherty M. 2003. Living on the edge: Ecological and cultural edges as sources of diversity for social-ecological resilience. Human Ecology. vol 31(3): 439461.https://doi.org/10.1023/A:102502390 6459.

van Steenis CGG. 2006. Flora pegunungan Jawa. Bogor: Pusat Penelitian Biologi, Lembaga Ilmu Pengetahuan Indonesia (LIPI). 